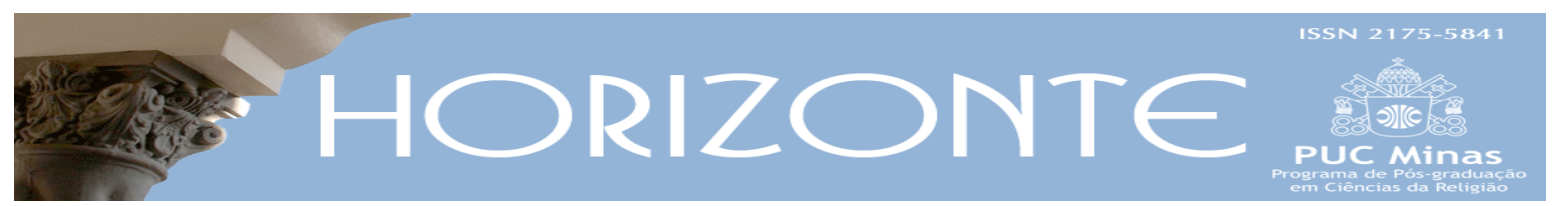

Temática Livre - Artigo Original

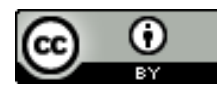

DOI - 10.5752/P.2175-5841.2017v15n45p206

\title{
Os Catecismos de Lutero e o uso da Escritura
}

\author{
Luther's Catechisms and the use of Scripture
}

\author{
Dr. Vicente Artuso ${ }^{1}$ \\ Dr. Carlos Jeremias Klein ${ }^{2}$
}

\begin{abstract}
Resumo
A terceira década do século XVI assinala a implantação da Reforma protestante na Alemanha e na Suíça. $O$ artigo trata inicialmente do contexto político e eclesial e das transformações religiosas na Alemanha, sob a liderança de Martinho Lutero. Para atender a premente necessidade de instrução religiosa do povo, o reformador publicou, em 1529, o Catecismo Menor e o Catecismo Maior. Em seguida, o artigo analisa a hermenêutica bíblica empregada nos catecismos. Destaca a primazia da Escritura na catequese adotando o princípio de que a Escritura se explica por si mesma tendo Cristo como centro. Lutero retoma da Igreja primitiva a insistência na Lectio Divina, porém distancia-se do método dos quatro sentidos, literal, alegórico, moral e anagógico, da antiguidade cristã e da Idade Média. Adota métodos próprios de interpretação. Por meio dos Catecismos Lutero deu ênfase a Palavra proclamada a ser acolhida na fé, uma vez que na sua época bem poucos cristãos tinham acesso ao texto pleno das Escrituras.
\end{abstract}

Palavras chave: Lutero; Reforma; Catecismos; Hermenêutica; Escritura.

\begin{abstract}
The third decade of sixteenth century marks the establishment of the Protestant Reformation in Germany and Switzerland. This article initially addresses the political and ecclesial context and religious transformations in Germany under the leadership of Martin Luther. To fulfill the pressing need for religious instruction of the people, the Reformer published, in 1529, the Small Catechism and the Large Catechism. It highlights the primacy of Scripture in catechesis, adopting the principle that the Scripture might be explained by itself, with Christ as center. Luther takes of early Church the method of Lectio Divina, but he distanced himself from the four-way method: literal, allegorical, moral and anagogical, from antiquity and the middle Ages. Through catechisms, Luther emphasized the Word proclaimed and accepted in Faith, since in his time very few Christians had access to the full text of Scripture.
\end{abstract}

Keywords: Luther; Reformation; Catechisms; Hermeneutics; Scripture.

\footnotetext{
Artigo recebido em 08 de março de 2016 e aprovado em 19 de fevereiro de 2017.

${ }^{1}$ Doutor em Teologia Bíblica, Mestre em Exegese Bíblica, pela PUC-Rio. Professor do Mestrado e Doutorado em Teologia da PUCPR em Curitiba-Pr. País de origem: Brasil. Email: vicenteartuso@gmail.com.

${ }^{2}$ Doutor e Mestre em Ciências da Religião, área de Teologia e História, pela Universidade Metodista de S. Paulo. Professor da UNIFIL em Londrina-Pr. País de origem: Brasil. Email: cjk_lond@yahoo.com.br.
}

Horizonte, Belo Horizonte, v. 15, n. 45, p. 206-238, jan./mar. 2017 - ISSN 2175-5841 


\section{Introdução}

O presente estudo analisa a forma de interpretação da Escritura nos Catecismos Menor e Maior de Martinho Lutero, publicados em 1529, no contexto das Reformas na Europa no século XVI. O tema é oportuno, em vista dos 500 anos da Reforma Protestante, em 2017.

O artigo, de forma breve, contextualiza a obra de Lutero. A conjuntura política e eclesial da época teve influência na composição dos catecismos e na sua forma doutrinal. As transformações religiosas na Alemanha, a instituição de igrejas territoriais em lugar das dioceses e a falta de instrução religiosa evidenciaram a necessidade da publicação dos catecismos, o que ocorreu em 1529. Os catecismos tiveram grande repercussão e se divulgaram rapidamente. Na Suíça, surgem catecismos de Ulrico Zwinglio, em Zurique, e de João Calvino, em Genebra. No mundo católico Pio $\mathrm{V}$ publica o Catecismo de Trento, obra que marcou a renovação da Igreja.

A parte mais extensa do artigo trata da hermenêutica bíblica nos Catecismos Menor e Maior. Destaca o apreço de Lutero pela Escritura e a primazia da pregação e ensino da Palavra de Deus. O estudo analisa os textos dos catecismos em que medida Lutero aplicou métodos próprios de interpretação, distanciando-se do método medieval dos quatro sentidos: “A letra ensina os fatos, a alegoria ensina o que se deve crer, a moral como se comportar, a anagogia o que se espera no futuro (escatologia)3. O sentido literal e moral com aplicação direta a vida e situação das pessoas é bem presente. Enfim o artigo mostra que a divulgação dos catecismos, a tradução da Bíblia acessível à linguagem do povo, a insistência na leitura e estudo da Escritura são contributos notáveis do reformador para uma volta às fontes do cristianismo mediante uma catequese que priorize a Bíblia como Palavra de Deus. 


\section{Martinho Lutero e a Reforma}

Nas reformas da Igreja na Europa, no século XVI, destaca-se, inicialmente, Martinho Lutero (1483-1546). Monge agostiniano, ordenado presbítero em abril de 1507, obteve, em março de 1509, o título de bacharel em Sagrada Escritura na Universidade de Wittenberg. A partir de 1511 fez estudos de Sagrada Escritura e Teologia nessa universidade, doutorando-se em 18 de outubro de 1512.

A véspera do dia de Todos os Santos do ano 1517 assinala o início da Reforma Protestante, com a afixação de noventa e cinco teses de Lutero sobre as indulgências, segundo a maioria das fontes, na Igreja da Universidade de Wittenberg. Em abril de 1521 o reformador compareceu à Dieta de Worms, perante o imperador Carlos V. Na volta de Worms, por ordem do Princípe-Eleitor da Saxônia, Frederico III, Lutero abrigou-se no Castelo de Wartburgo, por aproximadamente um ano. Ali traduziu o Novo Testamento para o alemão no transcurso de onze semanas, tendo sido publicado em setembro de 1522. A tradução completa da Bíblia, na qual participaram Filipe Melanchthon4, Justo Jonas5 e outros, levou doze anos, sendo publicada em 1534. Não foi a primeira em língua alemã, houve várias traduções entre 1466 e 1522. Não obstante, Ricardo Garcia-Villoslada observa:

Entre os méritos desta versão germânica [de Lutero] está não haver sido, como era frequente anteriormente, da Vulgata Latina, mas do original grego [...] atendendo o sentido mais que a letra; e em uma linguagem alemã tão viva, tão saborosamente popular, que todos a entendiam e gostavam, como se fosse um escrito originariamente germânico (GARCIAVILOSLLADA, 2008, p. 33-34).

Nos anos de 1523 e 1524 verifica-se tensão entre Tomás Müntzer (14901525), pregador em Allstedt, que foi um dos líderes da revolução dos camponeses. Em meados de 1524, Lutero escreveu "Carta aos Príncipes da Saxônia, sobre o

\footnotetext{
${ }^{4}$ Filipe Melanchthon (1497-1560) foi professor de grego e Hebraico a partir de 1518 na Universidade de Wittenberg. Escreveu Loci Communes, obra de teologia, a célebre Confissão de Augsburgo e uma Apologia da Confissão, documentos confessionais do luteranismo, além de outras obras.

${ }^{5}$ Justo Jonas (1493-1555) foi amigo e colaborador de Lutero. Estudou direito e teologia em Erfurt, chegou a Wittenberg em 1521.
} 
espírito revoltoso”. Em 1525, Lutero escreveu “Exortação à Paz: Resposta aos 12 Artigos do Campesinato da Suábia”, no qual adverte contra a deflagração da Revolução: “Quem lança mão da espada, à espada perecerá (Mt 26,52). Isso só pode significar que ninguém deve apelar para a violência por iniciativa própria (LUTERO, 1996, p. 313).

A partir de 1524, verificam-se avanços no movimento da Reforma com adesão de regiões ou cidades, como Magdeburgo, Nurenberg, Estrasburgo, Augsburgo, Esslinger e Ulm. A partir da Dieta de Spira (1526) foram organizadas "igrejas territoriais": "Foi abolida a antiga jurisdição dos bispos, o território foi dividido em distritos, cada um com um superintendente com autoridade espiritual sobre o clero paroquial e, por sua vez, responsável perante o Eleitor” (WALKER, 1967, p. 31).

\section{Os catecismos}

O cristianismo nasceu da experiência da fé em Cristo que se aprofunda no ensino centrado na Escritura. Porém, enquanto no primeiro milênio a Escritura era considerada fonte da instrução e da teologia, "no século XII, com Pedro Lombardo, começa-se a praticar uma teologia que é menos bíblica. Ao invés da Escritura ser a fundamentação da teologia, textos escolhidos eram usados para dar suporte a dogmática" (ARTUSO, 2013, p. 130). Na esteira da "volta às fontes" da Renascença, o século XVI assinala as Reformas protestante e católica na Europa.

Os catecismos de Lutero representam a evolução e o resultado de diversas catequeses do reformador centradas essencialmente na Escritura. Nos anos de 1516 e 1517, Lutero pregou sobre o Decálogo e o Pai-Nosso. Em 1519, a pedido de Jorge Espalatino, Uma breve instrução sobre como devemos confessar-nos. Nesse ano, surge a Trilogia sobre os sacramentos dedicada à duquesa Margarida de Braunschweig e Lüneburgo: Um Sermão sobre o Sacramento da Penitência, Um Sermão sobre o Santo Venerabilíssimo Sacramento do Batismo e Um Sermão 
sobre o Venarabilíssimo Sacramento do Santo e Verdadeiro Corpo de Cristo.

Em 1520 o reformador publicou três partes que posteriormente formariam a maior parte do Catecismo: Breve forma dos Dez Mandamentos, Breve forma do Credo e Breve forma do Pai-Nosso. "Em 1522, incluiu estas 'breves formas' em Um Livrinho dos Dez Mandamentos, do Credo, do Pai Nosso e da Ave-Maria, em que ensina a reconhecer o pecado e a orar". (WARTH, 2000, p. 320).

\subsection{O Catecismo Menor}

Em visitações ao Eleitorado da Saxônia e Meissen, em fins de 1528 e nos primeiros dias de 1529, Lutero constatou: "a lamentável e mísera necessidade experimentada recentemente, quando também eu fui visitador, é que me obrigou e impulsionou a preparar este catecismo ou doutrina cristã nesta forma breve, simples e singela. Meu Deus, quanta miséria não vi! $O$ homem comum simplesmente não sabe nada de doutrina cristã, especialmente nas aldeias" (LUTERO, 2000, 447).

O Catecismo Menor foi publicado em janeiro de 1529, provavelmente no dia 7, "em forma de cartazes para afixar nas igrejas, nas escolas e nos lares". ${ }^{6}$ Continha, inicialmente, três partes: os Dez Mandamentos, o Credo e o Pai-Nosso. É possível que contivesse também "Bênçãos e Graças", não foram preservadas cópias (WARTH, 2000, p. 321). Um segundo lote de cartazes surgiu em 16 de março desse ano trazia também Confissão, Litania, Batismo e Santa Ceia.

O Catecismo Menor foi publicado em forma de livro em 16 de maio de 1529 em Wittenberg, com o título "Catecismo Menor para os pastores e pregadores indoutos" (WARTH, 2000, p. 322). O Catecismo consta de perguntas e respostas, um método de aprendizagem para facilitar a memorização. Esse método era

\footnotetext{
6 Fritz Saxl (1989, p. 230) observa que os livros de Lutero e Melanchthon "são apenas uma fração aos panfletos que foram escritos. Dos manifestos de Lutero do ano de 1523, restam não menos que 189 [...] Tanto católicos como protestantes utilizaram palavra e imagem para o ataque e para a defesa".
} 
utilizado pelos hussitas, da Boêmia, há 60 anos, com seu livro "Questões para crianças”.

As partes do catecismo são:

- Os Dez mandamentos;

- O Credo;

- O Pai-Nosso;

- O Sacramento do Santo Batismo;

- Como se deve ensinar as pessoas a confessarem;

- O Sacramento do Altar;

- Orações;

- Tábua dos deveres.

Algumas observações se fazem pertinentes:

a. A enumeração dos "Dez mandamentos", no Catecismo de Lutero, segue a tradição que vem desde Agostinho, no ocidente, não mencionando Êxodo 20,4 e Dt 5,8-9 sobre a proibição de imagens esculpidas.7

b. O terceiro artigo do Credo, no Catecismo, reza: "Creio no Espírito Santo, uma santa Igreja cristã, a congregação dos santos, a remissão dos pecados, a ressurreição da carne e a vida eterna Amém".

Desde o século XV a expressão Ecclesia catholica era, costumeiramente, traduzida por "Igreja cristã" (LUTERO, 1980, p. 19, n. 2). A expressão “congregação dos santos" para a Igreja aparece também na Confissão de Augsburgo, sétimo artigo. Em resposta às críticas da Confissão formuladas na Confutatio, Melanchthon responde na Apologia: "Concedemos que nesta vida hipócritas e maus sejam misturados à igreja e dela sejam membros, segundo a sociedade externa dos sinais da igreja, isto é, da Palavra, da profissão e dos sacramentos [...] Nem são ineficazes os sacramentos em virtude de serem administrados por maus (MELANCHTHON, 1969, p.85).

\footnotetext{
${ }^{7}$ Os catecismos da Tradição Reformada (Catecismo de Genebra, de Heidelberg), porém, mantiveram como segundo mandamento a proibição de imagens de escultura no culto, como ocorre na Igreja Ortodoxa.
} 
c. A Confissão ou Penitência aparece intercalada entre o Sacramento do Batismo e o Sacramento do Altar. Nos primeiros escritos de Lutero encontra-se certa indefinição quanto ao número de sacramentos. Em "Do cativeiro babilônico da Igreja”, de 1520, o reformador não considera como sacramentos a Confirmação, o Matrimônio e a Ordem, alegando não estarem presentes nesses ritos "a promessa e o sinal". Quanto ao "Sacramento da Extrema-Unção", admite que na Carta de Tiago (5,14-15) aparecem a promessa (perdão dos pecados), e o sinal (unção com óleo). Questiona, todavia, se um apóstolo pode instituir sacramento: "Mesmo assim, ainda que fosse o apóstolo Tiago, diria que não é lícito que o apóstolo institua um Sacramento por sua autoridade, isto é, que estabeleça uma promessa divina, juntamente com o sinal, pois isso cabe somente a Cristo" (LUTERO, 1982, p. 133). Admite que a Penitência seja sacramento, mas lamenta os abusos ligados à mesma, como venda de indulgências. Todavia, considera a mesma "outra coisa não é que o caminho e o regresso ao Batismo". "Disso resulta que, se queremos falar a rigor, temos somente dois sacramentos, o Batismo e o Pão" (LUTERO, 1982, p. 140).

\subsection{O Catecismo Maior}

A primeira publicação, em abril de 1529, trazia o titulo de Catecismo alemão (Deutsch Katechismus). O nome "Catecismo Maior" (Grosser Katechismus) aparece na edição de 1541 .

O Catecismo Maior consta praticamente de três séries de sermões de Lutero em 1528, proferidos na congregação de Wittenberg. Na segunda edição, foi incluído no Catecismo a "Breve exortação à Confissão". As partes do Catecismo são:

- Os Dez Mandamentos de Deus;

- Os artigos principais de nossa fé;

- A oração, ou Pai-Nosso, que Cristo ensinou;

- Do Batismo;

- Do Sacramento do Altar;

- Breve Exortação à Confissão. 
O Catecismo Maior destinava-se a todos os cristãos, mas principalmente a todos os pastores e pregadores, para que se exercitem no seu conhecimento. Com efeito, Lutero exortava que ensinassem o catecismo que é "breve Suma e relato de toda a Sagrada Escritura...” (LUTERO, 2000, p. 325, n. 2).

\subsection{A Recepção dos Catecismos de Lutero}

Os catecismos de Lutero tiveram "incontestável influência na catequese católica, mormente nos países de língua germânica”. Frei Leopoldo Pires Ramos comenta em "Notícia histórica" da edição em português do Catecismo Romano, que os catecismos luteranos exerceram influência nesse catecismo, redigido por decreto do Concílio de Trento, e publicado por ordem do papa Pio V (IGREJA CATÓLICA, 1962, p 18).

A preocupação de Lutero com a educação cristã verificou-se também na esfera das Igrejas reformadas (Ulrich Zwinglio, João Calvino e João Knox): "Em Genebra, Calvino fundou escolas para proporcionar a todos educação elementar, e nessa educação os elementos religiosos e culturais estavam reunidos. João Knox, debaixo das influências de Calvino, iniciou reformas similares na Escócia”. (SMART, 1963).

No mundo luterano, a influência dos Catecismos de Lutero pode ser exemplificada pela inclusão no "Livro de Concórdia", de 1580, contendo todos os escritos confessionais que identificam os luteranos em todo o mundo: Os três credos formulados na Igreja antiga (Apostólico, Niceno-Constantinopolitano e Atanasiano), a Confissão de Augsburgo e a Apologia da Confissão (de Filipe Melanchthon), os Artigos de Esmalcalde, o Tratado sobre o poder e o primado do papa, os Catecismos Maior e Menor de Lutero e a Fórmula de Concórdia. O Catecismo Menor faz parte da Constituição de muitas Igrejas luteranas no mundo. Na Constituição da Igreja Evangélica de Confissão Luterana do Brasil (IECLB), 
Artigo $5^{\circ}$, é mencionado como expressão da fé, juntamente com a Confissão de Augsburgo, de 1530 e dos credos formulados na Igreja antiga. ${ }^{8}$

Em tempos recentes, quando questões em torno da teologia e prática do batismo surgiram na Igreja Evangélica de Confissão Luterana do Brasil, quanto à validade do batismo, o teólogo Gottfried Brakemeier citou e comentou a definição de Lutero no Catecismo Menor, condenando a prática do rebatismo, em sua "Réplica a Marcos Kruse", no artigo "Batismo e fé - sobre uma relação polêmica" (BRAKEMEIER, 2001, p. 47).

\section{Hermenêutica bíblica nos catecismos de Lutero}

Pode-se antever o apreço a Sagrada Escritura no catecismo, mediante o estudo do prefácio especialmente do catecismo maior. As citações no texto referemse ao documento dos catecismos Menor e Maior, de Lutero, inclusive do prefácio, conforme a paginação do Livro de Concórdia, São Leopoldo, Sinodal; Porto Alegre, Concórdia, 1980.

Lutero inicia dando grande ênfase ao ensino que não pode ser desprezado. Referindo-se ao valor do catecismo maior escreveu: "Essa obra é um breve compêndio e sumário da Sagrada Escritura toda” (p. 390). Compreende-se o motivo do tom fortemente parenético: "inculcamos o catecismo e queremos e solicitamos que seja inculcado" (p. 387). Esta expressão é inspirada na exortação do Deuteronômio sobre o ensino dos mandamentos (Dt 6,7-8) (p. 389). Lutero denuncia a negligência dos pastores e pregadores no ensino (cf. n.1). Estavam mais preocupados com seu bem estar "como se fossem pregadores por causa do estômago" (p. 388). A expressão ecoa a denúncia de Miquéias contra os falsos profetas: "Se tem algo para morder em seus dentes, proclamam: Paz" (Mq 3,7)!

\footnotetext{
${ }^{8}$ A tradução do Novo Testamento por Lutero, em linguagem popular, publicada em 1522, "abriu espaço para uma catequese orientada e direcionada" (PAULA, 2004, p. 174).
} 
Lutero continua exortando os responsáveis pelo ensino, os pregadores: "Que leiam pela manhã, ao meio dia e á noite uma ou duas páginas do catecismo, do livrinho das orações, do Novo Testamento ou de outra parte da Escritura" (p. 387). "Ocupar-nos da palavra de Deus, dela falar e meditar é auxílio poderoso contra o diabo e as tentações" (p. 388) Por isso "deverias "prazerosamente ler, recitar, meditar e tratar essas partes mesmo que nenhum outro proveito tivesses senão o de afugentar o diabo e os maus pensamentos" (p. 388). Se não bastasse para admoestar-nos a que leiamos o Catecismo dia após dia, já o só mandamento de Deus deveria ser o bastante para obrigar-nos seriamente como ordena ele no Deuteronômio (Dt 6,7-8) que meditemos sobre os mandamentos, assentados, andando, parados ao nos deitarmos, ao levantarmos, e que os tenhamos diante dos olhos e nas mãos como marcas.

Esses textos do prefácio mostram que os pregadores devem estar formados pela Palavra de Deus. Ela é "a alma do Catecismo", e seu conteúdo forma o pregador para depois formar os fiéis em Cristo. A insistência na leitura, estudo, meditação do catecismo e da Palavra de Deus tornará fecundo o trabalho do pregador e tornará vivaz o testemunho dos cristãos. Aqui se resgata a leitura orante, prática presente nos primeiros padres da Igreja. Lutero refere o valor da leitura espiritual: "É que o Espírito Santo está presente com esse ler, recitar, e meditar, e concede luz e devoção sempre nova e mais abundante, de tal forma que a coisa dia a dia melhora em sabor" (p.388). Portanto a Palavra de Deus na vida transforma, dá um novo significado, um novo sabor, um novo sentido a existência. O cristão se tornará "sal da terra" e "luz do mundo".

Ocupar-se dos mandamentos e das palavras de Deus "é a água benta e o sinal da cruz verdadeiros que espanta o diabo". Mais adiante arremata citando Rm 1,16: "A palavra é poder de Deus" (p.289). "Que nome daremos a palavra de Deus, que espanta e aniquila esse mestre de mil artes..." ? (Referindo-se ao diabo). A Palavra de Deus "certamente deve ser mais do que mestre de cem mil artes"! "E nós desprezaríamos tal poder, proveito, força e fruto com tanta leviandade, 
especialmente os que queremos ser pastores e pregadores"? (p. 389). Esse questionamento visa a retomada da leitura bíblica e volta à genuína fonte da vida cristã.

Outro aspecto que chama atenção é o valor dos mandamentos em vista do mandamento principal que resume toda a Escritura: "Quem entende os dez mandamentos bem e inteiramente deve entender a escritura toda. Assim pode aconselhar, ajudar, confortar, julgar e decidir em todas as coisas e casos" (p .390). De fato o catecismo começa com o estudo dos mandamentos. O decálogo estudado e meditado no contexto do deuteronômio (Dt 6,4-5; 4,35) e dos ensinamentos de Jesus sobre o mandamento principal (Mc 12,28-34) conduz ao entendimento da essência do ensinamento da Escritura. Trata-se aqui do binômio "lei e evangelho" que desempenha um papel importante na compreensão das Escrituras na teologia de Lutero. Assim, "Os Artigos de Esmalcalde”, escritos pelo reformador em 1537, declaram:

Mas a função principal da lei é revelar o pecado hereditário, com os frutos e tudo e mostrar ao homem a que tremenda profundidade sua natureza caiu [...]. O Novo Testamento mantém essa função da lei e também insiste nela, como faz Paulo em Rm 1, onde diz: "A ira de Deus é revelada do céu sobre todos os homens [...]". O Novo Testamento acrescenta imediatamente, através do evangelho, a consoladora promessa de graça, na qual cumpre se creia. É, como diz Cristo em Marcos 1: "Arrependei-vos e crede no evangelho", isto é, “Tornai-vos outros e procedei de maneira diferente e crede em minha promessa (LUTERO, 1980, p. 324-325)

Bengt Hägglund sintetiza o pensamento do reformador: "Lei e evangelho caracterizam duas espécies de pregação, que agem simultaneamente, a lei acusa e julga, enquanto o evangelho suscita a fé no coração e assim soergue o homem e o recria para que possa amar a Deus e a seu próximo” (1986: p. 190)9.

\footnotetext{
${ }^{9}$ O próprio esquema dos catecismos inclui de forma inseparável: Lei (decálogo) e Evangelho (Credo, Pai Nosso, Sacramentos). Trata-se de colocar as bases em que se crê (quid credendum) para viver "a fé agindo pela caridade" (Gl 5,6). É isso que conta, segundo Paulo. A Lei, com a plenitude no amor, aqui se insere na dinâmica da fé.
} 


\subsection{A interpretação da Escritura no catecismo menor.}

Os dez mandamentos seguido do creio e o Pai Nosso são as partes mais importantes para crer e não duvidar (Tg 1,6-7). Os mandamentos são citados no rodapé (Ex 20,2-17; Dt 5,6-21), mas o texto do catecismo é apresentado de forma catequética mais resumida. O primeiro mandamento é explicitado com detalhes no catecismo maior. Acentua-se a fé e confiança absoluta na soberania de Deus, fonte de todas as graças. Por isso pareceria mais adequado que a formulação do decálogo fosse precedido da frase: "Eu sou o Senhor teu Deus que te fez sair da terra do Egito, da casa da escravidão" (Ex 20,2; Dt 5,6). O texto acentuaria a gratuidade de Deus que precede a lei. Porém, em algumas edições desde o séc. XVI, apenas a apresentação “Eu sou o Senhor teu Deus" são colocadas como introdução dos mandamentos (p. 367, nota). Comenta Milton Schwantes que os mandamentos valem por causa do "eu” que os propõe. Ele não propõe por causa de algum dever absoluto, mas por causa da libertação. Ex 20,2 indica que os mandamentos estão embasados na libertação e não o inverso (SCHWANTES, 1988, p.10-11). O Senhor é "eu sou" enquanto atua gratuitamente, vê, ouve, conhece as angústias do povo e desce para o libertar (Ex 3,7).

O catecismo apresenta os dez mandamentos numa forma catequética bem clara e acessível. A conclusão depois do décimo mandamento faz menção da ira e a misericórdia do Senhor até mil gerações para aqueles que o amam e guardam seus mandamentos (Ex 20, 5-6) Aqui se fala da ira e da misericórdia na medida do amor. A observância dos mandamentos vem depois do amor. Amar é o verbo que move a observância plena de cada um dos mandamentos. Mas a formulação do texto indica que a misericórdia de Deus depende da observância: usa de misericórdia para "aqueles que o amam e observam seus mandamentos." A introdução do decálogo em Ex 20,2 menciona a ação gratuita de Deus libertador anterior ao dom da Lei. 
O segundo capítulo sobre o Credo, o símbolo apostólico, reduz ao essencial a teologia cristã. Os artigos de fé foram agrupados em três temáticas: a criação (Deus Pai) a redenção (Jesus Cristo) e a santificação (O Espírito Santo). O que dá a entender que o conteúdo da fé (fides quae), os artigos do creio não necessitam ser tão acentuados, mas sim a fé fiducial, isto é a resposta do ser humano a Palavra de Deus (fides qua). Daí o motivo do terceiro capítulo sobre o Pai-Nosso ser bem explicitado em sete petições que expressam toda confiança do fiel em Deus Pai. O catecismo segue a versão do Pai Nosso de Mateus 6,9-13. O justo vive da fidelidade de Deus para com ele ( $\mathrm{Rm} 1,17)$.

O quarto capítulo versa sobre o Batismo. No primeiro artigo, fala da água ligada a palavra de Deus. Refere-se ao Batismo no contexto do mandamento em Mt 28,19, que ordena de ensinar e batizar. Nesse texto o ensino da palavra de Deus precede o Batismo como sacramento. Este é realizado com a fórmula litúrgica plena em nome da Trindade Santa. No segundo artigo o catecismo fala dos efeitos do Batismo. Primeiro explica os efeitos salvíficos e depois reforça com a Escritura em Mc 16,16: “Quem crer e for batizado será salvo, quem não crer será condenado”. No terceiro artigo volta as falar da palavra de Deus unida á agua que realiza o batismo. Para confirmar recorre a Tito 3,5-8 que trata do "lavar regenerador e renovador do Espírito Santo" "a fim de que justificados por sua graça sejamos herdeiros da vida eterna”. Este texto apenas reafirma o efeito da água do batismo: o lavar seguido do renascimento no Espírito Santo. O quarto artigo explica o que é imersão em água (p. 376). Significa “morrer com todos os pecados e ressurgir diariamente”. O ensino é fundamentado em Rm 6,4 que associa o batismo ao mistério pascal da morte e ressurreição com Cristo. Pode-se observar que a Escritura vem depois da explicação para dar autoridade a doutrina no método de perguntas e respostas. Porém há catecismos, bem posteriores a Lutero no estilo de perguntas e respostas que não citam a Bíblia.

O quinto capítulo explica como a pessoa deve confessar. O confessor pergunta ao penitente: “crês que o meu perdão é o perdão de Deus"? O penitente 
responde "Sim amado senhor". Então o confessor dirá "Como crês assim seja contigo". Esta frase é tirada do relato da cura do servo do centurião (Mt 8,13) e inserida no contexto da confissão dos pecados. A fórmula da absolvição no catecismo é formada com base nos textos de Mc 5,34; Lc 7,50; 8,48. Vemos que textos são destacados de um contexto não penitencial e usado em uma estrutura do rito do perdão. A Escritura é usada em vista da construção de uma fórmula litúrgica.

Em relação ao sexto capítulo que explica o sacramento do altar, a fórmula das palavras da ceia também resulta de uma combinação de textos (1Cor 11,22-25; Mt 26,26-28; Mc 14,22-24; Lc 22,19-20).

O sétimo capítulo trata da oração. Como o chefe de família deve ensinar a sua casa a orar de manhã e de noite: A oração começa em nome do Pai, do Filho e do Espírito Santo, seguida do Creio, o Pai-Nosso e outra oração de pedido de perdão. É ensinada também a oração de bênção antes das refeições. A oração de agradecimento que segue é uma formulação fielmente fundada nos Salmos 106,1; 136,$25 ; 147,9-11$ (p. 380).

Depois é apresentada uma tábua de deveres cristãos. São uma coletânea de versículos para todas as "santas ordens e estados". A exortação é dirigida aos Bispos, Pastores e Pregadores (1Tm 3,2-6; Tt 1,6-9). Explica o que os cristãos devem fazer em relação aos seus mestres e curas d'alma. Dar o salário a quem vive do Evangelho é reconhecer o salário do trabalhador do reino (Lc 10,7; 1Cor 9,14; Gl 6,6-7; Dt 25,4; Lc 10,7; 1Tm 5,17-18; 1Ts 5,12-13; Hb 13,17). Lutero nesses textos enfatiza o direito dos pregadores receberem seu sustento, e serem ouvidos e respeitados nos seus ensinamentos. Exceto o texto de Hebreus, as outras sete citações tratam da relação dos cristãos e seus deveres para com a manutenção do clero. Isso se explica devido à situação de abandono dos ministros da palavra. Lutero queixava-se daqueles que "deixam cair as paróquias em ruínas e permitem que os pastores e pregadores sofram miséria e fome a valer" (p. 387). 
O catecismo apresenta também os deveres com a autoridade secular (Rm 13,1.2.4) deveres dos súditos para com o governo (Mt 22,21; Rm 13,1.5-7; 1Tm 2,12; Tt 3,1; $1 \mathrm{Pe} 2,13-14$ ) deveres dos maridos (1Pe 3,7; Cl 3,19) das esposas (1Pe 3,1.6) exortação aos pais (Ef 6,4) aos filhos (Ef 6,1-3) aos empregados, empregadas, jornaleiros e trabalhadores (Ef 6,5-8), aos patrões e patroas $(\mathrm{Ef} 6,9)$, à juventude em geral (1Pe 5,5-6), às viúvas (1Tm 5,5-6) a os cristãos em geral (Rm 13,9; 1Tm 2,1). Quase todas essas exortações são tiradas dos códigos domésticos do Novo Testamento e orientam para o bom comportamento e a moral cristã das pessoas conforme seu estado de vida. É um tratado de moral extraído totalmente da Escritura e adaptado a vida cristã. Consta de vinte e sete citações da Escritura. Isso indica a prioridade da catequese: formar para uma vivência da ética cristã fundada no Novo Testamento.

Há pelo menos cinco textos de exortações á obediência às autoridades e nenhum texto que exorte as autoridades como tratar os súditos. O leitor cristão atual esclarecido no contexto democrático esperaria exortações aos chefes: “quem quiser ser grande seja como aquele que serve", "aquele que preside, presida com solicitude”. Nesse aspecto Lutero não é revolucionário e aconselha a obediência. Talvez a exortação a obediência seria mais oportuna num contexto em que os fracos eram oprimidos. Nesse caso a submissão evitaria um grande mal: a violência e morte dos oprimidos caso se rebelassem. A exortação a caridade em Rm 13,9 é dirigida a todos, mas no contexto dá a entender que se destina apenas ao povo por ser colocada no final. Sabe-se que as exortações à submissão às autoridades como vindas de Deus, na história foram usadas para justificar a tirania dos governos. Uma coletânea de exortações a obediência a autoridade se presta a uma interpretação ideológica que não leva em conta o princípio do amor cristão. Tornase necessário uma hermenêutica que traga um novo sentido por trás das palavras, um sentido espiritual para o presente. 


\subsection{A interpretação da Escritura no Catecismo Maior}

\section{a. Os Dez Mandamentos}

O primeiro mandamento se apresenta com a forma "Não terás outros Deuses”. Lutero explica levantando a pergunta: “Que significa ter um Deus ou que é Deus"? Então responde: “Deus, designa aquilo de que se deve esperar todo o bem e em quem devemos refugiar-nos em todo momento de aperto (p. 394) O sentido desse mandamento é exigir fé e confiança de coração (p. 395). Confiança, fé inseparável de Deus, crer no Deus único, são as palavras mais presentes no seu longo comentário. Transgredir esse mandamento é confiar em "outro deus". O outro deus é Mâmon (p. 395). Lutero se baseia em Mt 6,24, Lc 16,13, para afirmar que Deus é inseparável do crer. O comentário acentua sempre a oposição, como aparece no Evangelho: Não se pode servir dois senhores, não podeis servir a Deus e ao Dinheiro (Mt 6,24). Mâmon é o dinheiro, bens em que se põe o coração todo. É o que se gruda e adere a natureza até a sepultura. Ter outros deuses significa praticar a idolatria. "Procurar ajuda e consolo e salvação nas próprias obras e presumir de forçar a Deus de abrir as portas do céu, com número de doações, de missas, de jejuns é fazer de Deus um ídolo” (p. 397). É ele que nos dá todos os bens corporais e eternos (p. 398). As criaturas, os outros que nos fazem o bem são o canal, o meio através do qual Deus concede todo o bem (p. 398). Francisco de Assis nos seus louvores ao Altíssimo dizia: “Tu és o bem, o sumo Bem, o Deus vivo e verdadeiro”.

Deus não quer tolerar nenhuma presunção e nenhuma confiança em qualquer outra coisa e não exige de nós coisa maior do que uma confiança cordial que dele espera todo o bem (p. 401). Nesse aspecto cita 1Sm 15,11 Fala que Saul fracassou porque se afastou de Deus, se apegou ao poder (cf.1 Sm 10; 15; 16; 31; 2Sm 4), enquanto Davi, perseguido e pobre foi escolhido para o reinado. O comentário é detalhado sobre Ex 20,5-6, pois é a conclusão ao primeiro mandamento e também encabeça os demais mandamentos (p. 399). No catecismo menor é comentado no final dos mandamentos. "A ira não cessa até a quarta 
geração ou grau, o favor ou bondade, por outro lado estende-se a muitos milhares”. Lutero comenta esse texto dizendo que Deus não deixa sem vingança o desviar-se dele, e não cessa de estar irado até a quarta geração, até extirpá-los de todo. Aqui Ex 20,6 destaca a justiça de Deus e depois a misericórdia. Deus quer ser temido e não desprezado. Porém, por terríveis que sejam essas palavras, comenta Lutero, mais poderoso é o consolo existente na promessa dos que se apegam em Deus podem estar certo de que ele quer mostrar-se misericordioso até mil gerações (p. 400). O comentário de Lutero é para reforçar a confiança e apego em Deus e não fala do amor e da observância dos mandamentos como é explícito em Ex 20,6. A interpretação visa sempre destacar a confiança absoluta em Deus e não nas obras. No entanto a fé se relaciona com o amor. Fé é o cumprimento do primeiro Mandamento. Uma fé concreta visível na prática do amor, torna compreensível não só o primeiro mandamento, mas todos os mandamentos. Lutero fala a esse respeito no "Sermão sobre as boas obras" de 1520. No amor e na observância dos mandamentos estão incluídas a gratuidade e a cooperação humana com as obras do amor, duas dimensões inseparáveis da Aliança de Deus com a humanidade. Esta questão das obras para a justificação foi bastante discutida em uma tentativa de conciliação o discurso da Igreja católica foi considerar as obras como preparação para a justificação, pois é Deus quem justifica mediante a fé.

No comentário ao segundo mandamento: "Não tomarás o nome de Deus em vão", explica que a honra verdadeira ao nome de Deus consiste em esperar dele todo o consolo (p. 405). Ainda que se invoque o nome dele no momento de aperto, se lhe rende louvor e graças. Lutero então cita o Sl 50,15 "Invoca-me no dia da angústia: eu te livrarei, e tu me glorificarás”. O nome de Deus é santificado na oração do Pai Nosso junto com os pedidos do perdão das dívidas, do pão de cada dia (p.404)

Quanto ao terceiro mandamento: "Santificarás o dia do descanso”, Lutero recorre à Escritura, mas não cita os textos sobre o sábado judaico. Sabat significa cessar de trabalhar. No antigo testamento Deus separou o sétimo dia, instituindo-o 
por dia de repouso e ordenando que fosse santificado acima dos demais (p. 406). Refere, porém, que o mandamento do sábado dado aos judeus, tem as marcas de outra cultura (p. 407). Cristo nos desobrigou das exigências do sábado no antigo Testamento, mas para oferecer uma compreensão cristã. Lutero menciona a interpretação muito estreita dada no passado com o abuso do preceito a ponto de não tolerar em Cristo obras que eles mesmos praticavam em dia de sábado (p. 406). Então em relação a postura de Cristo sobre o sábado são citados vários textos. Cristo mirava que santificassem o dia santo, o descanso. Ele trouxe a verdadeira compreensão do dia de sábado.

A força desse mandamento diz Lutero não é feriar, porém santificar. Nesse dia cabe uma especial atividade santa, que é prestar culto e dedicar-se a palavra de Deus (p. 409). Na verdade, a importância da palavra de Deus é tão grande que sem ela nenhum dia de descanso é santificado (idem). Para livrar-se da tentação do diabo diz Lutero "É necessário que tenhas a palavra de Deus continuamente no coração, nos lábios e nos ouvidos” (p. 410). Vê-se aqui o fundamento profundamente bíblico do comentário sobre a observância do sábado como santificação do tempo com base em Dt 6,4-6. Com razão Lutero fala que não basta ouvir a missa no domingo ou ouvir a leitura do evangelho que logo esquecem. Propõe um domingo ativo com ensino da palavra, com ouvir, aprender e reter. Aqui Lutero faz afirmação em prol da escuta da palavra: "É mandamento de Deus, que te pedirá contas de como ouviste, aprendeste e honraste sua palavra”. O Domingo seria o dia mais apropriado para estudo, escuta e oração com a palavra de Deus. Isso não era realizado. A preocupação é resgatar o valor da palavra, a mística cristã. Enfim a intenção é promover uma catequese bíblica, participativa que avive a fé. $\mathrm{O}$ sabat ou dia do Senhor é o momento privilegiado para se santificar e santificar o tempo com a palavra de Deus.

Quanto ao quarto mandamento Honrarás a teu pai e a tua mãe, Lutero explica que "honrar", não abrange apenas o amor, também a modéstia, humildade e reverência como para uma majestade oculta" na pessoa do pai e da mãe. (p. 411). 
Cumpre incutir nos jovens que vejam nos pais representantes de Deus e advirtam que mesmo nas suas fraquezas, são pais e mães dados por Deus (idem). Obra boa e santa por excelência é prestar aos pais honra e obediência (p. 412). Se honra os pais também por meio de atos, servindo, ajudando e cuidando deles quando idosos e enfermos (p. 412). Lutero baseia-se na literatura sapiencial ao falar do bem resultante desse mandamento: "Quem guardar esse mandamento haverá de ter bons dias, felicidade e prosperidade”. Porém retoma o decálogo Ex 20,12; Dt 5,16, que fala da vida longa: "Para que se prolonguem os teus dias na terra em que habitas". Paulo retoma e vigorosamente enfatiza: "Honra teu pai e tua mãe, - é o primeiro mandamento com promessa - para seres feliz e teres vida longa sobre a terra” (Ef 6,2-3). Enfim Lutero fala dos pais espirituais que nos governam e presidem mediante a palavra de Deus e cita Paulo como exemplo: "Eu pelo Evangelho vos gerei em Cristo Jesus” (1Cor 4,15).

Quinto mandamento: Não matarás. O mandamento significa: A ninguém devemos fazer mal, não com as mãos, ou por atos, depois não com a língua para advogar ou aconselhar tais atos Que o coração não deseje mal a ninguém, nem por ira ou ódio (p. 423). O texto mais importante citado sobre o mandamento é Mt 5,20-26 assim resumido no catecismo: “que não se matará, nem com mão, coração, boca, sinais, gestos”, nem auxiliando e aconselhando (p. 422). Pode-se matar também omitindo ajuda, alimento, a quem passa fome e nos pede: "Tive fome e não me destes de comer, sede e não me destes de beber..." (Mt 25,42-43) (p. 423). Enfim a intenção de Deus com esse mandamento é não permitir qualquer dano e sofrimento e que demonstremos todo bem até mesmo aos inimigos: "amai vossos inimigos e orai pelos que vos perseguem" (Mt 5,44) (cf. p. 424). Vemos a interpretação positiva do mandamento "não matarás", significa não só não tirar a vida, mas promover o bem, com ações, palavras, com o coração e desejando sempre o bem de todos. Para os cristãos o significado do mandamento se amplia a luz da caridade evangélica no sermão da montanha (Mt 5-6) e no sermão do juízo final (Mt 25). 
O sexto mandamento "Não adulterarás" tem o escopo de ensinar que tenhamos o cuidado de evitar qualquer forma de causar dano ao próximo (p. 425) como no mandamento anterior. Mas nesse caso trata-se do cônjuge que forma uma só carne e sangue com ele. A explicação está ancorada em Gn 2. Diz Lutero que o mandamento tem em vista o adultério, porque a ordem não adulterarás entre os judeus tornava o matrimônio obrigatório a todos (p. 425). O que se quer nesse mandamento que cada um tenha vida casta e ajude o próximo a fazer o mesmo. No aspecto positivo a castidade conjugal é vivida quando os cônjuges se amam mutuamente e se honrem. Aqui Lutero se baseia em $\mathrm{Ef}$ 5,22-25 e Cl 3,18 onde fala do amor entre marido e mulher deve ser como o amor de Cristo pela Igreja. Na base da castidade conjugal está o amor "Quem ama a sua mulher ama-se a si mesmo" (Ef 5,28), pois a união, o amor matrimonial os torna uma só carne (Ef 5,31) (cf. p. 428). Para Lutero "onde a natureza impera tal como foi implantada por Deus, não é possível manter-se casto fora do casamento" (p. 427). Assim só com o matrimônio se pode viver a castidade, exceto alguns que "por meio de elevado e sobrenatural dom podem manter-se castos fora do casamento". Aqui parece aludir a 1Cor 7,7-9 àqueles e aquelas que por dom de Deus não optaram pelo casamento.

O Sétimo mandamento: Não furtarás. O mandamento é muito abrangente. Inclui não causar dano ao próximo, não subtrair vantagem se apropriando indevidamente de qualquer bem, nem em transações de compra e venda, cumpre ainda proteger o alheio (p. 428) e até ajudar e emprestar aos pobres. Esse aspecto da caridade é fundamentado com Prov.19,17: "quem se compadece do pobre ao Senhor empresta e este lhe paga o seu benefício". Lutero exorta duramente aqueles que roubam os pobres, "raspas até ao osso, e além disso despachas com altivez a pessoa a quem deverias dar de graça, então a pobreza vai embora miserável e tristonha". "Guarda-te disso como do próprio diabo" (p. 432-433). Aqui não cita a Bíblia, mas a denúncia evoca Mq 3,3 que denuncia os chefes que "comem a carne e arrancam a pele do povo".

O oitavo mandamento: "Não dirás falso testemunho contra o teu próximo". "Este mandamento proíbe todo pecado da língua que possa causar dano ou magoar 
o próximo” (p. 435). Positivamente significa proteger a honra e boa reputação do próximo (p. 434). Que cada qual ajude o próximo no sentido de lhe garantir o seu direito. Trata-se também de não falar mal dos outros, mesmo que sejam culpados (p. 436). Ao invés de falar mal, o procedimento correto diz Lutero é ater-se ao Evangelho em Mt 18,15 "Se teu irmão pecar vai corrigi-lo a sós, se ele te ouvir ganhaste o teu irmão”. Portanto reprender pessoalmente é a forma correta e não difamar e prejudicar a honra do irmão mesmo que ele seja culpado (cf. p. 437-438). Lutero interpreta de forma acomodatícia 1Cor 12,22-23 que "os membros mais frágeis do corpo merecem mais cuidado e os que parecem menos dignos a estes damos maior honra; e os que são menos decentes revestimos de maior honra”. Assim diz Lutero "Devemos velar o que em nosso próximo é desonroso e falho, e, com tudo o que em nós está, servir a sua honra, ajudar naquilo que lhe é útil, e prevenir também o que lhe possa trazer desonra” (p. 439). A hermenêutica acomoda um texto com sentido eclesiológico, em função do mandamento de não revelar o lado fraco do irmão para proteger sua honra. A imagem da Igreja é o corpo onde cada membro tem uma função, um dom espiritual colocado a serviço de todos. No corpo eclesial os membros devem ser solidários e se ajudarem mutuamente, em especial os fracos e os pobres, pois todos tem a mesma dignidade em função do corpo.

Nono e décimo mandamentos: Não cobiçarás a casa do teu próximo. Não cobiçarás sua mulher, empregado, empregada, gado, nem coisa alguma que lhe pertença.

O sentido desses mandamentos é que ninguém deve pensar e tomar o propósito de assenhorar-se daquilo que é dos outros, como a mulher, empregados, casa e lar, campos, gado, prados. A mulher era como a propriedade do homem que tinha sobre ela poder de despedi-la por um termo de divórcio conforme Dt 24,1. (p .440) Assim os judeus tinham de andar prevenidos, de que alguém deseja-se a mulher de outro (idem). Lutero cita o mau exemplo do rei Herodes que ainda em vida do seu irmão se casou com a mulher deste. Assim mesmo quis ser considerado 
como homem honrado e íntegro (Mt 14,3 e Mc 6,17-28). (p. 442)

O catecismo fecha o tratado dos mandamentos, exaltando o decálogo como modelo de doutrina divina sobre o que devemos fazer para agradar a Deus. Retoma o texto de Ex 20,5-6 que era um anexo do primeiro mandamento. Sendo que o primeiro mandamento perpassa todo o decálogo, diz Lutero, convém inserir na conclusão o mesmo texto da conclusão do primeiro mandamento (p. 444-445). Assim toda a Escritura pregou e inculcou, por toda a parte, esse mandamento e orientou tudo para o temor de Deus e a confiança nele. É o que faz Davi, ao longo do Saltério: “Agrada ao Senhor os que o temem, e os que esperam na sua misericórdia” (Sl 147,11) (p. 445). Esse versículo é como se dissesse: Agrada-se o Senhor dos que não têm outros deuses. Pois temer o Senhor é confiar nele como Deus único.

\section{b. O Pai-Nosso}

Nos mandamentos ouvimos o que se deve fazer e no Credo o que se deve crer. Lei e Evangelho são inseparáveis. Quem crê na palavra, é justificado por Cristo e aceita a Lei e os mandamentos para viver na fidelidade ${ }^{10}$. Visto que não podemos cumprir os mandamentos perfeitamente, é necessária a oração, "clamando e pedindo que o Pai que nos dê, preserve e multiplique a fé e o cumprimento dos dez mandamentos”. Lutero, no seu comentário do Pai-Nosso, incentiva a pedir, pois é certo que ele nos atende. Para motivar a oração constante cita o Sl 50,15 "Invoca-me no dia da angústia: eu te livrarei” e a seguir o Evangelho “pois todo o que pede recebe" (Mt 7,7-8) (p. 459). Lutero faz a ligação com os mandamentos, pois a oração visa de fato o cumprimento dos mandamentos. "Vimos no segundo mandamento: Não tomarás o nome de Deus em vão", significa

\footnotetext{
${ }^{10}$ A questão da necessidade da Lei para os justos foi objeto de controvérsias entre os teólogos luteranos do século XVI. A Declaração sólida da Fórmula de Concórdia (1580) procura harmonizar, reconhecendo a função da lei na vida cristã, "Acontece porém, que nesta vida os crentes não são renovados perfeita e completamente, completive vel consummative. Pois ainda que os pecados deles estão cobertos pela obediência perfeita de Cristo, de modo que não são imputados aos crentes para a condenação, estando também iniciadas pelo Espírito Santo, a mortificação do velho homem e a renovação de suas mentes no espírito, todavia o velho homem ainda Ihes está cravado na natureza e em todos os seus poderes internos e externos" (LUTERO, 1980, p.605).
} 
positivamente que louvemos o santo nome, o invoquemos em todas as necessidades, ou oremos”.

Seja esta a primeira e mais necessária das partes do "Pai Nosso", pois todas as nossas orações devem apoiar-se na obediência a Deus (p. 459-460) e toda a nossa defesa e proteção está unicamente na prece (p. 461). "Santificado seja o teu nome”. Significa que Deus se torna santo entre nós, quando nossa vida e doutrina são divinas e cristãs (p. 462) Observa Lutero que nessa parte pedimos exatamente o que Deus exige no segundo mandamento, a saber, que não se abuse do seu nome para jurar, amaldiçoar, mentir, enganar, mas que seja usado de maneira proveitosa em louvor e honra a Deus (p. 462). Santificar quer dizer "louvar, exaltar e honrar", com palavras e obras. O pedido de santificar liga-se também a observância da palavra. Nada honra mais a Deus que ser gratos e pedir para observar sua palavra e que a palavra seja ensinada de maneira pura e ser considerada preciosa e de valor (p. 463).

"Venha o teu Reino". O que significa Reino de Deus? Lembra Lutero, Reino não é outra coisa o que ouvimos no creio. Significa que Deus enviou ao mundo a Cristo, seu Filho, nosso Senhor, para que nos redimisse e libertasse do poder do diabo e nos levasse a ele (p. 463). Fala da "vinda do reino de Deus a nós”, mas não cita a Escritura. A vinda ocorre de duas maneiras: aqui no tempo mediante a palavra e a fé e na eternidade pela revelação. Não pedimos uma esmola, mas um tesouro eterno (pg. 464). Termina citando o texto do sermão da montanha: "Buscai em primeiro lugar o reino de Deus, e todas estas coisas vos serão acrescentadas" (Mt 6,33; Lc 12,31). Na oração o Reino é pedido, e pedindo se busca esse reino com todos os bens que lhe são inerentes.

"Faça-se a tua vontade, assim na terra como no céu”. Nossa natureza está inclinada ao mal ainda que tenhamos aceitado a palavra de Deus e nela crido. O mundo é perverso e mau por isso o cristão deve buscar, pedir, para que seja feita a vontade de Deus. Lutero então comenta a partir do Evangelho sem citar. "Onde a palavra de Deus é pregada, aceita ou crida e produz fruto, aí também não há de 
faltar a amada cruz. Ninguém pense que vai ter paz. Deverá ao contrário sacrificar o que tiver na terra: bens, honra, casa e lar, mulher e filhos, corpo e vida. Isso dói a nossa carne e ao velho homem. A palavra de ordem é perseverar e sofrer” (p. 466). Aqui está um aspecto da vida cristã, do seguimento de Jesus: Fazer a vontade de Deus é assumir o projeto e suas consequências. O comentário liga a petição do Pai nosso, ao seguimento de Jesus, que inclui perseguição e cruz. Mais uma razão para que o pedido seja insistente.

"O pão nosso de cada dia nos dá hoje”. Aqui se considera as necessidades do corpo "o pobre cesto de pão". Pede-se o necessário, o pão cotidiano, e também todos os bens necessários para toda a vida em todos os aspectos. À vida não pertence apenas o que o corpo precisa como alimento, vestuário e outras coisas, mas também tranquilidade e paz no relacionamento com as pessoas (p. 467). Lutero também "constata a miséria no mundo, por causa da moeda falsa, da alta de preços, e mais ainda por causa daqueles que oprimem os pobres e os privam do pão de cada dia! Verdade que temos de suportar isso. Mas eles que se precavenham e não suceda perderem a intercessão comum e se acautelem para que esta parte do Pai Nosso não se volte contra eles” (p. 468-469). Não se observa apelo á solidariedade e partilha, daqueles que possuem, mas exortação para que os pobres sejam prevenidos. Talvez para dizer, que se organizem e trabalhem para ter o pão de cada dia!

"E perdoa-nos as nossas dívidas, assim como nós perdoamos aos nossos devedores". Trata-se antes de tudo de reconhecer e aceitar o perdão. "Perdoe as nossas dívidas". "Não é que não perdoe o pecado, ele nos ofereceu o perdão antes e nos presenteou com o Evangelho, no qual outra coisa não há que o perdão antes mesmo que tivéssemos pedido ou pensado nele" (p. 469). Porém "assim como nós perdoamos aos nossos devedores" significa que tudo está redimido e perdoado sob a condição de que também perdoemos. Aqui Lutero comenta a luz do sermão da Montanha: "Se tu não perdoas não penses que Deus perdoa a ti" (p. 470): "Perdoai e sereis perdoados $($ Lc 6,37) e depois do Pai Nosso ainda acrescenta "porque se 
perdoardes aos homens as suas ofensas, também vosso pai celeste vos perdoará” (Mt 6,14). Os textos bíblicos são comentados no contexto da fé. É preciso reconhecer que Deus perdoa e já nos ofereceu o perdão antes de pedir. Esta afirmação é uma acomodação do texto: Deus sabe o que necessitamos antes mesmo de pedirmos. É certo que somos predestinados a ser santos desde sempre (Ef 1) mas a resposta de fé é que dá o perdão. De fato nos Atos dos Apóstolos na pregação de Pedro a fé precede o perdão e remissão dos pecados.

"E não nos deixes cair em Tentação". O tema da tentação do diabo é bem presente nos escritos de Lutero. Ele começa falando do esforço e trabalho para reter o que pedimos e nelas perseverar. Embora tenhamos recebido o perdão, e sejamos íntegros e de boa consciência, temos de pedir que ele não nos deixe cair em tentação (p. 470-471). Há a tentação da carne, do mundo, e do diabo. Na carne nos arrasta o velho homem com suas paixões. No mundo que nos impele a cólera e impaciência. Ali imperam o ódio, a inveja, inimizade, violência, injustiça, vingança, imprecação, orgulho, soberba. Por fim o diabo que tenta para desprezarmos tanto a palavra como a obra de Deus. Seu propósito é arrancar-nos da fé, da esperança e do amor e levar-nos a superstição, falsa arrogância e obstinação. Aqui Lutero atualiza o texto de 1Tm 3,7, dizendo "esses são os laços do diabo" e como diz Ef 6,16 "os dardos inflamados do maligno”. Nessa citação da Escritura Lutero retira apenas uma expressão do contexto, que não é tanto a tentação, mas uma exortação a “empunhar sempre o escudo da fé para extinguir os dardos inflamados do inimigo". O “não nos induzir-nos em tentação” quer dizer que Deus nos dá poder e vigor para resistir, porém sem que a tentação seja tirada ou anulada (p. 472). Mas livra-nos do mal. Amém. Em grego está "livra ou guarda-nos do mau ou do maligno". Parece falar claramente do diabo. Pois é o diabo que coloca obstáculos para que não se realize tudo o que pedimos (p. 473) Além do mais o diabo é mentiroso e também pai da mentira como diz João (Jo 8,44). Esta petição está colocada em último lugar, pois se é para sermos protegidos contra todo mal e libertados do diabo, necessário se faz que seja santificado seu nome, esteja em nós o reino, e se faça a sua vontade. 


\section{c. $\mathrm{O}$ credo}

Segundo Lutero "o credo apresenta tudo o que devemos esperar e receber de Deus” (p. 447). Em breves palavras ensina a conhecer plenamente a Deus em vista de praticar o que está nos dez mandamentos. Mais adiante acrescenta embora que são doze artigos de fé. "Se fosse tomar uma por uma das partes que estão na Escritura e pertencem ao credo, haveria muito mais artigos”. Lutero propõe resumir o credo em três artigos principais que correspondem às três pessoas da Divindade: O Pai (criador), O Filho (redentor) O Espírito Santo (santificador). Com isso, no catecismo volta à forma primitiva esquemática do credo. Sesboué (tomo 1, 2002, p.79-82), expõe a origem da forma ternária do credo nas célebres fórmulas paulinas (1Cor 12,4-6; Ef 4,4-6). Relata que a Didaqué (ano 150, 7,1) testemunha o uso de um credo ternário no contexto batismal: "Para o batismo, batizai desta maneira: após ter dito antes de tudo o que precede batizai em nome do Pai, e do Filho, e do Espírito Santo, na água corrente”. Assim as perguntas iniciais do catecismo sobre a trindade introduzem o cristão no mistério da Salvação e são compêndio de todo o credo. Por isso também nas orientações sobre a oração devese iniciar dizendo "Em nome do Pai, e do Filho e do Espírito Santo. Amém”. "Tratase de um só Deus, uma só fé, porém três pessoas, e por isso também três artigos ou confissões” (p. 447-448). Hipólito de Roma (cerca de 220) testemunha a tríplice imersão, em resposta a confissão de fé em Deus Pai todo poderoso, em Jesus Cristo, Filho de Deus e no Espírito Santo (HIPÓLITO, 1981, p. 52).

Primeiro Artigo: Creio em Deus Pai, Todo Poderoso, criador do céu e da terra. Lutero explica o mais necessário do artigo, a criação. Diante da pergunta: Que significa creio em Deus Pai onipotente, criador...? A resposta é "creio que sou criatura de Deus, isto é que ele me deu a vida e sem cessar conserva, corpo, alma e vida, todos os membros, razão e inteligência etc. (p. 448). Essa resposta está fundamentada no primeiro mandamento: "Não terás outros Deuses”. O cristão tem sua fé alicerçada em Deus: "Eu sou o Senhor teu Deus”. Por isso deve responder e formular sua fé dizendo: "Eis o meu Deus, o Pai que fez o céu e a terra” (p.449). Ele 
é Deus Pai, todo poderoso, criador do céu e da terra. Lutero considera o mistério da criação de Deus em chave antropológica: "De onde viemos? Para onde vamos? O ato de fé no Deus criador dá novo significado a existência. Tudo é obra dele. Em Deus vivemos, nos movemos e somos” (PEDROSA, 2004, p. 274).

Segundo Artigo: E em Jesus Cristo, seu único Filho nosso SENHOR, o qual foi concebido pelo Espírito Santo, nasceu da Virgem Maria, padeceu sob Pôncio Pilatos, foi crucificado, morto e sepultado, desceu ao inferno, no terceiro dia ressuscitou dos mortos, subiu ao céu, está sentado a direita de Deus Pai Todo Poderoso, donde há de vir para julgar os vivos e os mortos.

Perguntam: Que crês no segundo artigo, a respeito de Jesus Cristo? A resposta é "Creio que Jesus Cristo, verdadeiro Filho de Deus, se tornou meu Senhor. Tornar-se nosso SENHOR significa que ele me redimiu do pecado e da morte, e de toda desgraça” (p. 450). O Deus criador é também salvador, pois no seu amor misericordioso veio ao encontro da humanidade enviando seu Filho. Lutero não explora a dimensão escatológica do Senhorio de Cristo. "Quando todas as coisas lhe tiverem sido submetidas, então o próprio Filho se submeterá aquele que tudo lhe submeteu para que Deus seja tudo em todos” (1Cor 15,28).

Terceiro artigo: "Creio no Espírito Santo, uma santa igreja cristã, a congregação dos santos, a remissão dos pecados, a ressurreição da carne e a vida eterna. Amém". É o artigo que Lutero intitula de "Santificação". Creio que o Espírito Santo me santifica como o seu nome indica. Diante da pergunta: "Como se realiza a santificação"? A resposta: “Assim como o Filho obtém o domínio, pelo qual nos conquistou através do seu nascimento, morte, ressurreição, et., da mesma forma o Espírito Santo efetua a santificação por intermédio da congregação dos santos que é a Igreja cristã, por intermédio do perdão dos pecados, a ressurreição da carne e a vida eterna” (p. 452). Ainda Lutero explica que Cristo nos conduz a sua santa congregação, nos coloca no seio da Igreja, pela qual nos prega Cristo e nos conduz a Cristo (cf. p. 452). Então santificar não é outra coisa senão conduzir ao Senhor para receber os bens da salvação pela pregação da palavra. Para Lutero a 
“comunhão dos santos” é a congregação dos cristãos no Espírito Santo sob uma só cabeça Cristo (cf. p. 454). Essas explicações se fundam nas cartas Paulinas, embora Lutero não cite a Escritura. Em 1Cor 1,2 os "cristãos são santificados em Cristo e chamados a ser santos com todos os que invocam o nome de Nosso Senhor Jesus Cristo".

O Credo é uma síntese da Escritura formulada em artigos. Segundo Lutero para o cristão basta simplesmente crer. Por isso não houve a preocupação em explicar com mais detalhes o símbolo apostólico, alargando o significado com citações bíblicas. A fé confiança na promessa de Deus é a única atitude adequada diante da palavra de Deus. Assim para ele passam para segundo plano as questões acerca da racionalidade e estrutura da fé, assunto explicado, mais tarde no Catecismo de Trento e outros catecismos da Igreja Católica (SECKLER; BERCHTOLD, 1992, p. 308).

\section{d. O Batismo}

Lutero, no Catecismo Maior, afirma que ao homem simples basta saber, da Escritura, os textos dos Evangelhos de Mateus $(28,19)$ e de Marcos $(16,16)$, tal como afirmara no Catecismo Menor.

$\mathrm{Na}$ terceira década do século XVI surgiram grupos sectários que desvalorizavam os sacramentos, alegando "ser o Batismo coisa externa e que coisa externa de nenhuma utilidade é”. Lutero replica: “O que Deus institui e ordena, não pode ser coisa vã, senão que deve ser coisa cabalmente preciosa [...] Ser batizado em nome de Deus, e ser batizado não por homens, mas pelo próprio Deus. Por isso, ainda que levado a efeito por mãos humanas, não obstante é verdadeiramente obra de Deus mesmo” (p. 475). Àqueles que questionavam: “Que ajuda haveria de levar à alma um pouquinho de água?”, responde: “Como te atreves a interferir assim na ordem de Deus e arrancar-lhe a melhor joia com que Deus a ligou e em quem a encerrou, e da qual não a quer separada? Porque o cerne da água é a Palavra o ou 
mandamento de Deus" (p. 476) Em seguida, cita Santo Agostinho: Accedat verbum ad elementum et fit sacramentum.

Quanto ao efeito do Batismo, Lutero além de citar novamente Mc 16,16, aduz que em Tito 3,5 Paulo chama o Batismo de "lavacro de regeneração".

A seguir Lutero discorre sobre questões como a relação entre fé e batismo e batismo infantil, sem recorrer a textos bíblicos. Uma referência bíblica implícita ( $\mathrm{Rm}$ 6,1-4) aparece ao referir-se ao "terceiro Sacramento, a penitência, "o qual, propriamente, outra coisa não é que o Batismo. Pois, que outra coisa significa penitência senão atacar o velho homem com seriedade e entrar em nova vida?” (p. 484).

e. O Sacramento do Altar

Lutero elabora as palavras da instituição do Sacramento do Altar combinando o texto de 1 Co 11,23-25 com a narrativa dos sinóticos, Mt 26,26-28; Mc 14,22-24 e Lc 22,19-20, a saber:

Nosso Senhor Jesus Cristo, na noite em que foi traído, tomou o pão, deu graças e o partiu e deu aos seus discípulos e disse: Tomai, comei, isto é o meu corpo, que é dado por vós. Fazei isto em memória de mim. Por semelhante modo, depois da ceia, tomou também o cálice, deu graças e lho deu e disse: Este cálice é o novo testamento no meu sangue, que é derramado por vós, para remissão dos pecados. Fazei isto, todas as vezes que o beberdes, em memória de mim (p. 486).

O Sacramento do Altar "é o verdadeiro corpo e sangue de Cristo Senhor, em e sob o pão e o vinho ${ }^{11}$, que a palavra de Cristo ordena a nós cristãos comer e beber [...] O Sacramento é pão e vinho, mas não simples pão e vinho, como os que ordinariamente se põem na mesa, senão pão e vinho compreendidos na Palavra de Deus e a ela ligados" (p. 487). Tal como no comentário ao Batismo, o reformador volta a citar Santo Agostinho: Accedat verbum ad elementum et fit sacramentum.

${ }^{11}$ Ver “Confissão de Augsburgo", In: LUTERO, 1980, p. 32, n. 44. 
Quanto aos que recebem o sacramento, Lutero observa que não devem afastar-se do sacramento pessoas débeis e frágeis, citando Santo Hilário: "Se um pecado não é de natureza tal, que se possa com razão excluir pessoa da congregação e considerá-la como não cristã, não deve a gente abster-se do sacramento" a fim de não se privar da vida (p. 492-493). Adiante, o reformador cita Mt 9,12: "Os sãos não precisam de médico, e sim os doentes".

Aos que alegam não sentir fome e sede do Sacramento, Lutero aconselha a leitura de Gl 5,19 sobre as "obras da carne" e Rm 7,18: "Porque eu sei que em mim, isto é, na minha carne, não habita bem nenhum". "Se S. Paulo ousa dizer isso de sua carne, não vamos nós querer ser melhores e mais santos [...] Em suma, quanto menos sentes o teu pecado e a tua imperfeição, tanto mais razão tens para ir ao sacramento e procurar ajuda e remédio (p. 495).

\section{À guisa de conclusão}

1 Os catecismos de Lutero divulgaram a doutrina cristã que deriva das próprias Escrituras Sagradas, e seu conteúdo é Lei e Evangelho. Lutero retoma a Lectio Divina, dos quatro passos (leitura, meditação, oração, contemplação) de forma unitária, e simplificada. Ele parece clarear melhor o sentido literal inseparável do sentido espiritual. Assim "prazerosamente ler, recitar, meditar" (p. 388), já é simultaneamente se alimentar da Palavra, em vista de um novo ver e agir na fé (contemplação). O Objetivo de buscar o sentido literal e moral é mais evidente mediante escolha de textos direcionados a tocar as pessoas de diferentes estados e condições sociais. É o caso da parênese do Novo Testamento, inserida no Catecismo Menor mediante coletânea de textos em forma de síntese.

2 O princípio luterano de que a Escritura se explica por si mesma e que um texto é explicado por outro aparece no Catecismo (BRAKEMEIER, 2003, p .42). Um exemplo claro é o comentário do Batismo. Lutero fala da água e da Palavra ao comentar Mt 28, porém a menção da água é implícita, e a teologia do batismo vai ser completada com a citação de Tt 3 que explicita os efeitos do batismo e fala do 
"lavar para a regeneração" Nesse método a Bíblia é também citada para compreender melhor a doutrina no catecismo. Essas descobertas doutrinais são congruentes com o Evangelho e aqui obtidas através da Escritura, uma vez que segundo Walter Altmann (2016, p.124) “o princípio 'Sola Scriptura' não é um dogmatismo da letra, mas admite-se nos textos uma reserva de sentido" por traz das palavras. Além de textos literais da Escritura, Lutero recorre a autoridade de Santo Agostinho e Santo Hilário no comentário aos sacramentos do Batismo e da Eucaristia. Assim dá a entender que Palavra de Deus também está na palavra proclamada.

3 O prefácio ao Catecismo Maior dá ênfase ao ensino do Catecismo como síntese da Escritura. O que é constatado na exortação com o verbo "inculcar" usado tanto para o ensino do catecismo como também da Palavra de Deus. O contexto eclesial explica essa insistência devido a situação de abandono e ignorância religiosa do povo. No entanto evidencia-se o valor da palavra pregada e acolhida na fé. A exortação frequente a ouvir, acolher, meditar, ensinar as palavras de Deus, é bem presente em especial no comentário dos mandamentos. A insistência nessa exortação revela o esforço do reformador de realizar na Igreja uma volta às fontes genuínas do Cristianismo, as Escrituras Sagradas. Visava incutir o entendimento do sentido literal, que segundo Lutero não está separado do sentido teológico. De certa forma, repropõe a antiga prática da "Lectio Divina", com a recitação e meditação do texto presente nos primeiros padres da Igreja.

4 Há uma unidade no catecismo em torno do tema da confiança e fé na soberania de Deus do qual procede todo bem, não obstante a reivindicação da justiça punitiva de Deus aos pecadores. Na teologia de Lutero "Deus é”, enquanto salva e justifica o ser humano. Portanto a visão é existencial. Deus é, porque é acreditado. Por consequência o tratado do Credo é apresentado com brevidade. Com efeito, a resposta confiante do povo a Deus e sua palavra, é mais urgente dissertar o conteúdo doutrinal. O credo em si é um catecismo desde os primeiros séculos transmitido para ser acolhido e confessado. "Se confessares com a boca e creres em teu coração que Deus o ressuscitou dos mortos serás salvo" (Rm 10,9). 
5 Enfim a Bíblia como Palavra de Deus é “alma do Catecismo”, assim como é alma de toda a teologia cristã. Cristo é o centro das Escrituras e "ignorar a Escritura é ignorar Cristo" (S. Jerônimo). Segundo Brakemeier (2003, p. 42) "Sola Scriptura" se apoia essencialmente no "Solus Christus". É o Cristo "pro me" que se deu em favor da humanidade. Dessa forma mesmo textos do Antigo Testamento podem ser interpretados alegoricamente em vista de Cristo. E isso para Lutero era também sentido literal. Não havia ainda o estudo histórico-crítico e não se fazia distinção entre Bíblia e Palavra de Deus. Entretanto alguns autores do século XX (K. Barth, 1938; Watson, 1947; Ebeling, 1951) atribuíram anacronicamente a Lutero essa distinção (THOMPSON, 2009, p.300).

\section{REFERÊNCIAS}

ALTMANN, Walter. Lutero e a libertação - Uma leitura de Lutero em perspectiva latino-americana. São Leopoldo: Sinodal e faculdades EST, 2016, segunda edição.

ARTUSO, Vicente. A Bíblia e Catecismo da Igreja Católica. In: Antonio Luiz Catelan Ferreira. (Org.). Os 20 anos do Catecismo da Igreja Católica e o Ano da Fé. 1ed. Brasilia: Edições CNBB, 2013, p. 129-169.

BRAKEMEIER, Gottfried. A Autoridade da Bíblia: Controvérsias, Significado, Fundamento. São Leopoldo: Sinodal, Centro de Estudos Bíblicos, 2003.

BRAKEMEIER, Gottfried. Batismo e fé: sobre uma relação polêmica. Estudos Teológicos, São Leopoldo, v. 41, n. 2, 2001.

PAULA, Blanches De. Catequese no Mundo protestante. In: PEDROSA, V. M.; NAVARRO, M.; LÁZARO, J. (Orgs). Dicionário de Catequética. São Paulo: Paulus, 2004.

FITZMEYER, Joseph. A Bíblia na Igreja. São Paulo, Loyola, 1997.

GARCIA-VILLOSLADA, Ricardo. Martin Lutero 2: Em lucha contra Roma. Madrid: BAC, 2008.

HÄGGLUND, Bengt. História da Teologia. Porto Alegre: Concórdia, 1986.

HAUSER, Alan; WATSON, Duane. A History of Biblical Interpretation - vol 2. Michigan: Eerdmans, 2009.

HIPÓLITO DE ROMA. Tradição apostólica de Hipólito de Roma. Petrópolis: Vozes, 1981. 
IGREJA CATÓLICA. Catecismo Romano. Petrópolis, Vozes, 1962.

LUTERO, Martinho. Livro de Concórdia: As confissões da Igreja Evangélica Luterana. São Leopoldo: Sinodal; Porto Alegre: Concórdia, 1980.

LUTERO, Martinho. Do cativeiro babilônico da Igreja. São Leopoldo: Sinodal, 1982.

LUTERO, Martinho. Obras selecionadas, São Leopoldo: Sinodal; Porto Alegre: Concórdia, 1996, v. 6; 2000, v. 7.

MElanchthon, Filipe. Apologia da Confissão de Augsburgo. Porto Alegre: Concórdia, 1969.

PEDROSA, V. M. Criação. In: PEDROSA, V. M.; NAVARRO, V. M.; LÁZARO, J. (orgs.). Dicionário de Catequética. São Paulus, 2004.

SAXL, Fritz. La vida de las imagenes. Madrid: Alianza, 1989.

SCHMITT, Flavio. Interpretação bíblica em Lutero. In: Revista de Teologia e Ciências da Religião, Recife, Universidade Católica de Pernambuco, v. 3, n. 1, 2013.

SECKLER, Max; BERCHTOLD, Christoph. Fé. In: EICHER, Peter (Dir.). Dicionário de conceitos fundamentais de teologia. São Paulo: Paulus, 1992.

SESBOÜE, Bernard (Dir.). O Deus da Salvação. Tomo I, história dos dogmas. São Paulo: Loyola, 2005.

SCHWANTES, Milton. O Êxodo como evento exemplar. In: Estudos Bíblicos, Petrópolis: Vozes, n. 16, 1988, p.10-11.

SMART, J. D. El ministério docente de la Iglesia. Buenos Aires: Methopress, 1963.

THOMPSON, Mark D. Biblical Interpretation in the Works of Martin Luther. In: Alan J. Hauser and Duane F. Watson (Editors). A history of Biblical Interpretation. The Medieval through the Reformatio Periods. Michigan: Eerdmans, v. 2, 2009, p. 300.

WALKER, Williston. História da Igreja cristã. São Paulo: ASTE, 1967.

WARTH, Martin. Catecismos. In: LUTERO, Martinho. Obras selecionadas, São Leopoldo: Sinodal; Porto Alegre: Concórdia, 2000, v. 7. 